Ewa Jablońska-Deptula

\title{
KSIĄDZ WOJTEK
}

Katedra Warszawska 30 stycznia 1985. Południe. Wysoko — wśród tłumu ludzi góruje prosta, jasna trumna. Na niej stuła i kielich. Krzyż i płomyk zapalonego paschału. Odszedł do PANA kapłan, ksiądz archidiecezji warszawskiej. W koncelebrze ponad 150 kapłanów - pod przewodnictwem ks. Prymasa. Księża przybyli z wszystkich krańców Polski, podobnie jak setki młodych ludzi. Wśród nich habity różnych zgromadzeń zakonnych. Urywek z Ewangelii zaczerpnięty ze słów pożegnalnych Chrystusa w Wieczerniku. Zmarły sam go wybrał. Spiew błogosławieństw. Oczy pełne łez, a twarze jakby na przekór łzom rozradowane. Wszystkim zgromadzonym w owej wspólnocie Eucharystycznej, sprawowanej w mroźny, przedostatni dzień kończącego się roku towarzyszy świadomość, że Ten, którego zwłoki kryje trumna odszedł na wieczną wigilię do Chrystusa rodzącego się nieustannie w duszach ludzkich, że zgłębił w najbliższym, jakie dane jest czlowiekowi poznaniu, iż „BÓG JEST MIEOSCIAz”.

Rozpoczyna się liturgia ostatniego pożegnania. Rozbrzmiewa pieśń, która towarzyszyć będzie długiemu orszakowi ,żałobników" także na Powązkach, że ,Zmartwychwstał Pan”. W katedrze zapalają się setki płomyków świec uniesionych w górę przez uczestników Ruchu Światło-Życie, jakby w wielkim apelu serc. Zmarły był moderatorem ruchu oazowego. I kwiaty, mnóstwo kwiatów, które szybko tężeją w mroźnym powietrzu Powązek. Wśród wieńców - jeden niesiony przez delegację w ciemnych czapkach w kształcie kepi z zielonymi wypustkami - kolegów z gimnazjum im. Górskiego, którego był absolwentem.

Ks. Wojciech Danielski zmarł w pełni swego apostolskiego, żarliwego zaangażowania, dla wielu zupełnie niespodziewanie. Tylko nieliczni, których zobowiązał do absolutnej dyskrecji wiedzieli, że pierwsze przejawy choroby nowotworowej (czerniak kręgosłupa z licznymi następnie przerzutami) wystąpiły przed dwoma laty. A przecież jeszcze cały niemal lipiec i sierpień spędził za kierownicą - spotykając się z młodzieżą oazową w różnych zakątkach Polski.

W tym miejscu powinnam rozpocząc porządny zarys biograficzny uczonego, liturgisty, znakomitego dydaktyka, a przede wszystkim duszpasterza wielkiego formatu. Ale nie potrafię, dla mnie i moich bliskich pozostał księdzem Wojtkiem, Wojtkiem po prostu: Kapłanem, Kolegą Uniwersyteckim, Przyjacielem, Człowiekiem rozdającym uśmiech i siebie. To, co pragnęłabym przekazać jest niewyrażalne w słowach i może jedynie stanowić rodzaj ,fotograficznej” migawki jakby utrwalonej w kadrze nieporadnych zdań jednej z sylwetek ks. Wojtka.

Pierwsze zetknięcie - to Msze św. odprawiane w kaplicy Sióstr Niepokalanek w Warszawie przy ul. Idzikowskiego. Był to bodaj rok 1963, kiedy został tam kapelanem. Uderzyło mnie jego skupienie przy oltarzu i serdeczność w stosunku do sporej gromadki ministrantów. Nie znałam go wówczas bliżej, lecz nietrudno było dostrzec, że ma dar do dzieci. Sam promieniał czymś dziecięco radosnym, jakąś przezroczystą czystością.

Nasze drogi, choć wielokrotnie krzyżowaly się na KUL-u, zwłaszcza od 1964 r., gdy podjął tam prace jako asystent przy Katedrze Historii Kościoła w Sredniowieczu (a 1967 adiunkt Sekcji Pastoralnej Wydziału Teologicznego KUL) nie od razu zbliżyły się. Wielokrotnie konsultował się z moim mężem - Czesławem Deptułą - w rozmaitych poszukiwaniach tyczących kultu św. Wojciecha. Bywał w naszym skromnym „kołchozowym" pomieszczeniu na Sławińskiego, lecz były to jeszcze wizyty nie tyle przyjacielskie co koleżeńskie. Pracował nad swoją rozprawą magisterską, a potem doktorską o kulcie św. Wojciecha na ziemiach polskich. Dysku- 
towane z moim mężem kalendariograficzne zawiłości nie należały do tematów najbardziej mi bliskich, widoczna była natomiast pasja badawcza i zaangażowanie. Bo Wojtek cokolwiek robił - wkładał w to całego siebie. Wynik jego rozległej kwerendy to 752 kondeksy liturgiczne, nie licząc inkunabułów i starodruków. Niestety ów katalog dotychczas nie doczekał się publikacji. Nie należał do badaczy, którzy zazdrośnie strzegą monopol swojej wiedzy. Dzielił się szczodrze nią z kolegami i z tymi, z którymi prowadził zajęcia. Wielu księży może powiedzieć, że byli jego słuchaczami i to zarówno na KUL-u jak i w Instytucie Formacji Pastoralnej w Gorzowie, czy na Prymasowskim Studium Teologii Życia Wewnętrznego w Warszawie. Entuzjasta odnowy liturgicznej w duchu soborowym wygłosił wiele referatów dla duchowieństwa i zakonów wszystkich diecezji polskich, uczestniczył w przekładach zreformowanych ksiąg liturgicznych, współorganizował z ks. Franciszkiem Blachnickim sympozja pastoralno-liturgiczne w Krościenku nad Dunajcem. Każde dokonanie w tej dziedzinie było dla niego autentycznym powodem do radości. Nie chodziło tu jednak o teorię. On żył duchem odnowy liturgii. Widziało się to dopiero przy oltarzu. Dla tych, którzy wraz z nim i pod jego przewodnictwem przeżywali tajemnice Boże uobecniane w znakach liturgii na zawsze pozostana w pamięci słowa z jego testamentu:

„Dziękuję za takie serdeczne odnalezienie mojego PANA i PRZYJACIELA - JEZUSA CHRYSTUSA w adoracjach, w dobrych i bliskich ludziach, których otrzymałem, nade wszystko w świętych znakach Słowa Bożego i Liturgii, które są mi tak drogie, że sensu poza tym nie widze i w nauczaniu i pisaniu na KUL-u w praktyce, zwłaszcza w KUL-owskim Kościele Akademickim (wspólnota niedzielna godziny 11, kiedyś codziennie o 7.30, niezwykła wspólnota Misterium Paschalnego, także pogrzebów)".

Bliższy kontakt z ks. Wojtkiem (tak go zawsze nazywaly nasze dzieci) nawiązał się przy wczesnej I Komunii św. starszego syna. W przeddzień przyszedł do Tomka, by z nim przygotować hostię. Z całą powagą i uwagą potraktował 6-cio letniego chłopca, kiedy ten chcial z nim zostać jeszcze sam i porozmawiać w cztery oczy, zwierzyé się z czegoś. Uderzający był sposób udzielenia Komunii św. czwórce małych dzieci, z których jedno nie miało domu, gdyż jego rodzice byli alkoholikami.

Jego „rozdawanie siebie”, za które dziękował Bogu w swoim testamencie miało tyle spontaniczności i szczerości, zaparcia i nie szukania siebie, że ludzie lgnęli do niego instynktownie odnajdywali go w najtrudniejszych sytuacjach życiowych.

Gdy było już wiadomo, że nasz średni syn Wojtek ma nowotwór mózgu (i kręgosłupa) zwróciłam się do ks. Danielskiego o prowadzenie go. Był to rok 1973. Obowiązki wicedyrektora Konwiktu Księży na KUL-u, współpraca $z$ duszpasterstwem akademickim, przygotowywanie rozdziału o Liturgii - obciążyły go dodatkowo poza normalnymi, a bardzo licznymi obowiązkami dydaktyczno-naukowymi. Nie zapomnę wyrazu dobroci i troski na jego twarzy, gdy powiedział, że zgadza się, że jest do dyspozycji tego wówczas 7-letniego dziecka, któremu lekarze nie dawali żadnych szans przeżycia. W ciągu trzyletniej choroby naszego synka zrodziło się coś bardzo pięknego, czego trudno nawet dotykać słowami. Stanowi to bowiem tajemnice między ks. Wojtkiem, jego małym imiennikiem, a Bogiem. Ks. Danielski przy kolejnych pogorszeniach był na każde zawołanie, w dzień czy w nocy. Przed wezwaniem karetki pogotowia mającej dziecko przewieźć do Warszawy przychodził do nas z Komunią św. - dla wszystkich. On też udzielał Wojtkowi uroczyście w kaplicy konwiktu KUL-u sakramentu chorych. Było to w czasie kolejnej remisji, akurat na jego 9-te urodziny. Mieli też osobną umowę, że gdy Wojtka będzie bardzo bolało - wówczas pomyśli o swoim księdzu Wojtku, a on mu będzie towarzyszył w modlitwie. Była to rzeczywistośc, gdyż chłopiec zamiast 
skarżyć się mówił, że myśli o ks. Wojtku. Przyjaźń dziecka z kapłanem, które parę godzin przed śmiercią prosiło: „Wy mi napiszecie, że Bóg jest Miłością".

W ostatnim liście pisanym do ks. Wojtka Danielskiego w połowie listopada ub. r. wysłałam mu zdjęcie naszego Wojtusia i przypomniałam. że miał z nim umowę, która jest ponadczasowa. Odpowiedzią było parę słów telefonicznych z błogosławieństwem dla naszej rodziny.

I wreszcie pogrzeb Wojtka w Laskach w końcu października 1975 r. Nie wiem przez kogo dotarła do ks. Danielskiego wiadomość o jego zgonie. Był to chyba pierwszy pogrzeb w Polsce wedle nowej liturgii z triumfalnym paschałem przy małej trumnie. Homilia o wartości cierpienia dziecka. Ciepło i serdeczność, chociażby w ostatnim geście przed spuszczeniem trumny, kiedy ksiądz przykląkł, pocałował krzyż na trumnie mówiąc: „Pokój z tobą, Wojtku”.

Jego kapłańskiej posłudze zawdzięczamy tak wiele. On też przeprowadził rodzaj egzaminu naszej najmłodszej Marysi - przed wczesną pierwszą Komunią. Mam w oczach małą figurkę drepczącą poważnie obok księdza z konwiktu do kościoła akademickiego. Słowa Chrystusa: „Pozwólcie dzieciom przyjść do mnie" były dla niego czymś autentycznym.

Widywaliśmy się rzadko, na mszach w rocznicę śmierci Wojtka, niezapomnianych mszach. Na dziedzińcu KUL-owskim. Zawsze się śpieszył. Zatrzymywał się jednak, żeby choć parę słów zamienić, żeby się uśmiechnąć. Bolały go różne podłości, niesprawiedliwość dotykająca innych. Jego wrażliwość na krzywdę ludzką była wyjątkowa. Coraz bardziej rozrywany, coraz bardziej zajęty, a jednocześnie trwający w wewnętrznym skupieniu. Nie trzeba było słów, żeby wiedzieć, że można na niego liczyć. Gięęoko przeżywał sytuację w kraju. Pragnął, żeby nie była przeżyta w próżni, w zawieszeniu, żeby nagromadzony kapitał cierpienia człowieczego zaowocował w Bożym wymiarze.

Jego miłość do ludzi była uprzedzająca i wyprzedzająca. Gdy zabrakło mnie w domu w pierwszych dniach stanu wojennego przychodził, by spędzic parę nocy u nas. Lecząc się sam zatroszczył się o wszystkich znajomych, którzy potrzebowali jego pomocy. Innym razem na dziedzińcu uniwersyteckim powiedziałam mu o pewnej ludzkiej potrzebie. Natychmiast dał mi wszystkie pieniądze, jakie miał przy sobie.

Tęsknota za Tyńcem i wspólnotą zakonną, życiem bogomyślnym i coraz większy wir obowiązków, zwłaszcza tych administracyjno-gospodarczych, które męczyły go niesłychanie. Źrenicą jego oka stał się Ruch Swiatło-Życie, któremu poświęcił ostatek sił. Niewielu ludzi domyślało się jego cierpień fizycznych. Choroby, gdy ujawniła się w pełni, że niepodobna było jej ukryć - szturm modlitwy nie zdołał odwrócić, gdyż była ofiara z siebie:

„Ojciec w niebie przyjął do końca, dosłownie, moje kapłańskie ofiarowanie siebie, kiedy wiedział, że to dla dobra Kościoła i Polski najlepsze" (z listu pożegnalnego do Matki). Odeszłeś Wojciechu na wieczną Wigilię do PANA. Pokój z Tobą, Alleluja!

\section{Lublin}

EWA JABEOŃSKA-DEPTUEA 